\title{
Correction to: Recent progress on engineering microbial alginate lyases towards their versatile role in biotechnological applications
}

\section{Shivakumar Renuka Dharani ${ }^{1} \cdot$ Ramachandran Srinivasan $^{1} \cdot$ Regunathan Sarath $^{1} \cdot$ Mohandass Ramya $^{1}$ (D)}

Published online: 22 July 2020

(C) Institute of Microbiology, Academy of Sciences of the Czech Republic, v.v.i. 2020

\section{Correction to: Folia Microbiologica} https://doi.org/10.1007/s12223-020-00802-8

The original version of the article unfortunately contained an error.

A data was inadvertently added in the third author's name Regunathan Sarath. The correct author name is shown above. The original article has been corrected.

Publisher's note Springer Nature remains neutral with regard to jurisdictional claims in published maps and institutional affiliations.

The online version of the original article can be found at https://doi.org/ $10.1007 /$ s12223-020-00802-8

Mohandass Ramya

ramyam@srmist.edu.in

1 Molecular Genetics Laboratory, Department of Genetic Engineering, SRM Institute of Science and Technology, Kattankulathur, Tamil

Nadu 603203, India 